\title{
Effect of Porcine Cancellous Bones on Regeneration in Rats with Calvarial Defect
}

\author{
Kyeong Hoon Yoo, Se Eun Kim, Kyung Mi Shim', Hyun Jeong Park², Seok Hwa Choi ${ }^{3}$ \\ and Seong Soo Kang*
}

\author{
College of Veterinary Medicine, Chonnam National University, Gwangiu 500-757, Korea \\ ${ }^{1}$ Department of Radiology, Nambu University, Gwangiu 506-706, Korea \\ ${ }^{2}$ College of Veterinary Medicine, Jeju National University, Jgiu 690-756, Korea \\ ${ }^{3}$ College of Veterinary Medicine, Chungbuk National University, Cheongju 361-763, Korea
}

Received April 17, 2010 /Accepted August 25, 2010

\begin{abstract}
The purpose of this study was to evaluate the effect of porcine cancellous bone as a scaffold in a rat calvarial defect model. Critical-sized defects were created in 30 male Sprague-Dawley rats. The animals were divided into critical defect $(C D, n=10)$, $\beta$-tricalcium phosphate (TCP) graft $(B T, n=10)$ and porcine cancellous bone graft $(\mathrm{PCB}, \mathrm{n}=10)$ groups. Each defect was filled with $\beta-\mathrm{TCP}$ mixed with fibrin glue or porcine cancellous bone powder mixed with fibrin glue. In the CD group, the defect was left empty. All rats were sacrificed at 8 weeks after bone graft surgery, and bone formation was evaluated by gross observation, plain radiography, micro-computed tomography scanning and histological evaluation. Repair of bone defect was the least in the CD group, and significant new bone formation was observed in the PCB group. Grafting of porcine cancellous bone was more efficient for regenerating new bone than grafting $\beta$-TCP.
\end{abstract}

Key words : Bone graft, porcine cancellous bone, $\beta-\mathrm{TCP}$, calvarial defect, rat

\section{서 론}

혈액 다음으로 가장 빈번히 이식되는 조직인 골이식은 각종 골재건술(reconstructive orthopedic surgery) 및 척추골 융합 술(spinal fusion surgery), 불유합성 골절(nonunion fractures), 중증의 복합골절(highly comminuted fractures), 지연 유합(delayed union), 관절유합술(arthrodesis), 사지 구제술 (limb salvage), 구강 악안면 재건술(reconstruction surgery of Maxillofacial region) 및 치과용 임플란트 시술 등 매우 다양한 분야에서 광범위하게 이용되고 있으며 수의영역의 여러 분야 에서도 그 이용범위가 늘어가고 있는 추세이다[14].

현재까지의 골이식법 중 가장 이상적인 방법은 환자 자신에 게서 채취한 자가골을 이식하는 방법으로 자가골은 골결손 부위에서 골치유 및 골형성 과정에서 다른 골이식재에 비해 뛰어난 능력을 가지고 있다[7]. 그러나 자가골 이식법은 채취 시 전신마취, 부가적인 수술의 필요, 채취 부위의 통증, 골채취 량의 제한 등의 단점[2,9]을 가지고 있어 현재에는 자가골을 대체할 수 있는 동종골, 이종골 및 합성골의 쓰임이 점차 늘어 가고 있는 추세이다.

동종골은 동종의 사체나 생존해 있는 다른 공여자에게서 얻는 것으로서 이식재를 동결시키거나 동결건조, 탈회동결건 조, 그리고 방사선 조사, 고압 멸균 등을 가한 형태로 항원성을

\footnotetext{
*Corresponding author

Tel : +82-62-530-2877, Fax : +82-62-530-2809

E-mail : vetkang@chonnam.ac.kr
}

제거하여 면역반응을 최소화시켜 사용하게 된다[11]. 주로 사 람에서 동종골을 채취하는 방법은 고관절대치술(total hip replacement)에서 나오는 대퇴골두와 사체에서 얻게 되나, 사체 에서 채취하는 경우 살아있는 환자에서 채취할 때보다 4 배 정도의 세균 감염률이 높은 것으로 알려져 있다[3]. 이종골은 소나 돼지 등의 다른 종의 동물에서 골을 채취한 후 동결건조, 탈회동결건조, 그리고 방사선 조사압 및 열 멸균 등을 거쳐 골전도 능력을 기대하는 골이식재이다[8]. 그러나 이러한 동종 골과 이종골은 면역반응이나 교차감염면에서 $100 \%$ 안전하지 는 않다[18]. 이러한 단점을 보완하기 위해 최근 많이 사용되고 있는 골이식재가 바로 합성골이다. 합성골은 주로 사람 골의 주재료인 무기질을 인공적으로 합성한 것으로 동종골이나 이 종골에 비해 경제적이고, 쉽게 구할 수 있다는 장점을 가지고 있다. 현재까지는 동물뼈를 사용한 이종골이 구하기 쉬워 많 이 사용되고 있으나 $100 \%$ 감염에서 자유롭지 않아 합성골의 사용이 늘어가는 추세다[18]. 이들 재료는 골이 형성될 때 골소 주의 형성을 용이하게 하는 골전도 물질로 구분되고 있으나 자가골과는 달리 골형성능이 없으므로 자가골에 비해 골형성 에 필요한 기간이 길고, 새로 형성되는 골량도 자가골에 비해 크게 떨어지는 단점을 가지고 있다. 이러한 단점을 보완하기 위하여 최근에는 골형성을 유도하는 성장인자들을 같이 이식 하는 방법이 사용되고 있다[15]. 이러한 합성골의 대체물은 현 재 많은 소재들이 개발, 발전되고 있는데 그중 가장 대표적인 것은 수산화인회석(hydroxyapatite)으로 구조와 성분이 골과 유사하고 생체 친화성이 우수하여 1980년대 초부터 정형외과 
와 치과영역에서 관심의 대상이 되어 왔다[10]. 이러한 수산화 인회석은 이식부위에서 광물저장기(mineral reservoir)로서 작용하여 [6,19] 골전도 과정에 의해 골을 형성하게 된다고 보 고되고 있다[16]. 그러나 이식부위에서 섬유성 결합조직의 개 재 및 생체 흡수성이 매우 낮아서 자가골로의 치환이 거의 이루어지지 않고 오랫동안 체내에 남아있다는 단점들도 발생 하여 최근에는 이를 보완하기 위하여 칼슘과 인의 비가 2:1인 삼인산칼슘(tricalcium phosphate)에 대한 많은 연구가 이루 어지고 있다[4]. 또한 이종골 이식방법으로 돼지 해면질골을 처리하여 만든 이식재는 단독 혹은 자가골이나 다른 이식재 등과 혼합하여 사용되고 있는 재료이며 이미 많은 연구를 통 해 골전도성이 인정된 골이식재이다[11]. 보통 소의 해면질골 을 이용한 제품들이 많이 상품화되어 나오고 있으나, 본 연구 에서 사용된 이종골은 국내에서 최초로 개발된 돼지의 해면질 골을 처리하여 만든 제품으로 돼지의 대퇴골이나 경골을 추출 하여 골에서 지방성 골수를 $30 \% \mathrm{H}_{2} \mathrm{O}_{2}$ 를 이용하여 제거하고 다시 $90 \%$ 알코올을 이용하여 잔여 습기를 제거하여 12 시간 동안 건조시켜 $1,300^{\circ} \mathrm{C}$ 에서 고온 열처리하여 단백질 또는 유 기물질 등을 제거하여 면역반응을 최소화하였다[11]. 특히, 이 제품은 돼지에서 추출한 수산화인회석을 사용하여, 합성에 의 해 제조된 수산화인회석보다 화학적 구성이나 조직 구조가 실 제 뼈와 유사하기 때문에, 생체적합성이 뛰어나고, 기공이 서 로 연결되어 있어 새로 형성된 골조직이 기공 깊숙이 생성되어 생체역학적인 결합 강도를 높일 수 있다고 보고되고 있다[11]. 이에 본 연구에서는 돼지의 해면질골로 제조된 이종골의 골재생능 및 치유능을 확인하기 위하여, 랫드의 두개골에 임 계결손부를 형성한 후, 이전의 연구에서 골재생능이 입증된 베타 삼인산칼슘( $\beta$-tricalcium phosphate, $\beta$-TCP) $[1,12]$ 과 돼 지 해면질골을 동일한 방법으로 이식하여 육안적 소견, 방사 선 및 micro-CT 검사, 조직병리학적 소견을 비교 관찰하여 두 개골 결손부에 이식된 돼지 해면질골의 치유 및 골 재생능력 을 알아보고자 하였다.

\section{재료 및 방법}

\section{실험동물}

실험에 사용된 동물은 24 주령의 Sprageu-Dawley계 랫드 30 마리로 4 주령을 (주)샘타코 바이오 코리아에서 구입하여 임 계결손군 $(\mathrm{CD}$ 군, $\mathrm{n}=10)$, 베타 삼인산칼슘 이식군 $(\mathrm{BT}$ 군, $\mathrm{n}=10)$ 및 돼지 해면질골 이식군(PCB군, $\mathrm{n}=10)$ 으로 분류하였으며, 실 험동물은 온도 $23 \pm 3^{\circ} \mathrm{C}$ 와 습도 $50 \pm 10 \%$ 의 조건하에서 사료와 음수를 자유급식하며 20 주간 사육되었다. 동물의 사육과 실험 은 전남대학교 동물실험 지침에 따라 수행되었다

\section{골이식재}

BT군은 삼인산칼슘을 소재로 제작된 물질로 현재 치과용
골이식재로 상용화된 제품(Syncera ${ }^{\circledR}$, 오스코텍, 한국)으로 입 자의 직경이 0.4-1.0 mm인 구형의 분말형태를 사용하였다. 그 리고 $\mathrm{PCB}$ 군의 골이식재는 돼지의 해면질골을 처리하여 제작 된 생체세라믹 물질(TS-GBB ${ }^{\circledR}$, 태산솔루젼스, 한국)을 사용하 였다.

\section{골결손모델의 수술}

Ketamine $\mathrm{HCl}$ (케타민50주 ${ }^{\circledR}$, 유한양행, 한국) $40 \mathrm{mg} / \mathrm{kg}$ 과 xylazine (Rompun ${ }^{\circledR}$, 한국바이엘, 한국) $10 \mathrm{mg} / \mathrm{kg}$ 을 합제하 여 복강내 주사하여 마취를 실시하였고 마취 후 atropine sulfate (황산아트로핀 ${ }^{\circledR}$, 휴온스, 한국) $0.05 \mathrm{mg} / \mathrm{kg}$ 을 피하주사 로, enrofloxacin (바이트릴 50 주 ${ }^{\circledR}$, 한국바이엘, 한국) 2.5 $\mathrm{mg} / \mathrm{kg}$ 을 예방적 차원에서 근육 주사하였다. 두개결손부를 형 성하기 위하여 직경 $8 \mathrm{~mm}$ 크기의 bone trephine bur를 수술용 모터(Surgic XT Plus, Shanghai NSK international trading $\mathrm{INC}$, Japan)에 연결하여 두개부 중앙에 전층 결손부를 형성하 였다.

$\mathrm{CD}$ 군에는 이식재의 사용 없이 결손부 상방의 골막을 당겨 흡수성 봉합사(3-0 SURGISORB ${ }^{\circledR}$, Samyang Co., LTD, Korea) 를 이용하여 연속봉합법으로 봉합하였다. $\mathrm{PCB}$ 군에는 TS-GBB ${ }^{\circledR}$ 블록을 ronguer로 최대한 균일한 크기로 잘게 부수어 두개골 결손부에 이식하였고, BT군에는 Syncera ${ }^{\circledR}$ 구형의 분말형태를 두개골 결손부에 이식하였으며 이식 후 두 군 모두 골막을 단순결절봉합 하였다. $\mathrm{PCB}$ 및 BT군 모두 골이식 시 피브린 글루(Greenplast ${ }^{\circledR}$, 녹십자, 한국)를 사용하여 지혈의 효과를 얻음과 동시에 골이식재가 이식부위에서 다른 부위로 흩어지 는 것을 방지해 주었다. 마지막으로 모든 군의 피부는 비흡수 성 봉합사(3-0 black silk, AILEE CO., LTD, Korea)를 이용하여 단순결절 봉합법으로 봉합한 후 술부를 소독하였다.

\section{평가방법}

\section{방사선학적 평가}

골이식 후 4 주와 6 주에는 모든 실험군의 랫드를 주사마취 후에 치과용 방사선 장비(Port-X, 제노레이, 한국)와 오랄 센서 (Digi-X Sensor, 한진디지엑스, 한국)를 이용하여 $70 \mathrm{kVp}, 0.15$ $\mathrm{mAs}$ 조건에서 촬영하였고, 8 주차에는 모든 실험군을 희생시 킨 후 가검물을 채취하여 이전과 동일한 조건으로 방사선촬영 을 실시하였다. 영상분석은 TINA 2.10e. 이미지 소프트웨어 (Raytest, Straubenhardt, Germany)를 이용하여 흡광도 (Optical density)를 측정하여 골밀도를 평가하였다.

\section{Micro-CT 평가}

골이식 후 8 주차에 모든 실험군을 희생시켜 Micro-CT (skyscan 1172 Desktop X-ray Microtomograph, Skyscan, Belgium)를 이용하여 $50 \mathrm{kV}, 200 \mu \mathrm{A}$ 의 조건으로 스캔한 후에 NRecon Ver.1.4.4 (Skyscan, Belgium)를 이용하여 이미지화시 켜 각 실험군의 결손부의 단면 영상을 추출하여 평가하였다. 


\section{조직병리학적 평가}

조직검사를 위하여 골이식 후 8 주차에 모든 실험군을 희생 한 후 주위조직을 포함하여 결손부를 채취하고 $10 \%$ 중성 포르 말린 용액에 2일간 고정하였다. 각각의 표본은 포름산-구연산 나트륨 방법으로 탈회를 시행한 후 이식부의 중앙부를 중심으 로 $3 \mathrm{~mm}$ 두께의 절편 5 군데를 연속적으로 뽑아내어 수세한 후 조직 가공기를 이용하여 파라핀으로 포매한 후 블록을 만 들었다. 이 블록을 유합체와 평행하게 종단으로 다공체와 골 조직이 포함되도록 4-5 $\mu \mathrm{m}$ 두께로 조직절편을 만들어 Hematoxylin-Eosin 염색을 실시하여 광학현미경을 통하여 이 식부위의 염증세포 침윤, 신생모세혈관 증식, 섬유화, 파골 및 골모세포의 활성, 신생골 형성 및 골 성숙정도를 평가하였다.

\section{통계 처리}

통계적인 분석은 one-way ANOVA (SPSS version $14.0 \mathrm{~K}$ ) 를 사용하여 실시하였고, $\mathrm{CD}, \mathrm{BT}$ 및 $\mathrm{PCB}$ 군에서의 골형성정도 를 시기별로 비교하기 위해 Bonferroni 검정법을 이용하여 분 석하였다. 통계적 분석은 유의차 수준 0.05 에서 결과에 대한 가설 검정을 실시하였다.

\section{결과 및 고찰}

\section{육안적 평가}

본 실험에서 랫드 두개골 골견손부의 크기는 Schmitz 등 [17]이 말한 임계결손부 크기인 직경 $8 \mathrm{~mm}$ 로 하였으며 본 실 험 8주차 $\mathrm{CD}$ 군의 육안적 검사에서 결손부위가 약한 연부조직 으로 채워져 있는 것을 확인할 수 있었으며, 신생골로 보이는 구조는 관찰되지 않았다(Fig. 1A). BT군에서는 이식부위에서 이식재의 모습이 구형의 분말형태 그대로 남아있었고 이식재 끼리 서로 연결되어 있지 않고 변연부쪽으로 소량의 이식재가 빠져 나와 있는 것을 확인할 수 있었으며, 이식부위가 $\mathrm{CD}$ 군에 비하여 좀 더 강한 연부조직에 의해 싸여 있는 것을 확인할 수 있었다(Fig. 1B). $\mathrm{PCB}$ 군 역시 BT군과 마찬가지로 이식부위 에 이식재가 남아있는 것을 확인할 수 있었으나 BT군과는 달 리 이식재들이 서로 단단히 연결되어 있었으며 결손부의 변연 부 쪽으로 이식재가 빠져나가지 않고 이식부위에 잘 매립되어 있었으며 연부조직에 의해 감싸져 있는 것을 확인할 수 있었 다(Fig. 1C). 모든 군에서 육안상으로 염증반응은 관찰되지 않 았다.

\section{방사선학적 평가}

골이식 후 4,6 및 8 주차에 촬영한 방사선 사진을 오랄 센서 를 이용하여 이미지화 시킨 결과 4 주차 방사선 사진에서는 임계결손군의 두개결손부에서 특별한 방사선 비투과성은 보 이지 않았다. BT군과 $\mathrm{PCB}$ 군에서는 골밀도의 방사선 비투과성 이 관찰되었으며, 6 주차 방사선 사진에는 $\mathrm{CD}$ 군에서 4 주차와 비교하였을 때 연부조직의 방사선 비투과성이 관찰되기 시작
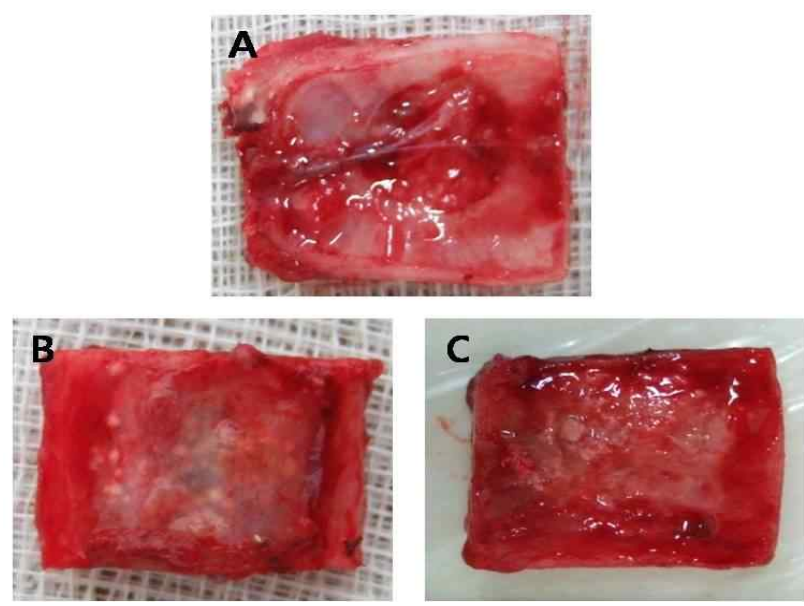

Fig. 1. Implantation sites of calvarial bone at 8 weeks post surgery. A: The surface of calvarial defect site was covered with a smooth thin layer of soft tissue with obvious a little vascularization on the surface in the $\mathrm{CD}$ group, $\mathrm{B}$ : There were residual $\beta-\mathrm{TCP}$ in calvarial defect site but the $\beta$-TCP composite dislocated in the calvarial bone defect and cohered strongly to the peripheral soft tissue in the BT group, C: There was residual porcine cancellous bone in calvarial defect site and cohered strongly to the peripheral soft tissue in the PCB group. No abscess or inflammation of the peripheral osseous tissues at the grafting site was observed in all groups. $C D=C$ ritical defect, $\mathrm{BT}=$ Beta-tricalcium phosphate, $\mathrm{PCB}=$ Porcine cancellous bone.

하였고 $\mathrm{BT}$ 군과 $\mathrm{PCB}$ 군에서도 4 주차보다는 방사선 비투과성이 증가한 것을 확인할 수 있었다. 그러나 변연부에는 여전히 방 사선 투과성이 관찰되었다. 또한 4 주 및 6주차에 실시한 방사 선 사진 상에서 골이식재의 입자들이 여전히 원형의 모습으로 보였고 돼지 해면질골 및 베타 삼인산칼슘의 입자 대부분이 주변으로 흩어지지 않고 이식 부위에 잘 유지되고 있는 것도 확인할 수 있었는데 이는 피브린 글루의 역할과 골막 봉합 시 이식재가 결손부에 정확히 매몰되도록 봉합한 것에 의한 것으로 고려된다. 8 주차에는 모든 실험군을 희생시킨 후 이식 부위의 정확한 평가를 하기위해서 가검물을 채취하여 방사선 촬영을 하여 평가를 하였다. $\mathrm{CD}$ 군은 두개결손부 변연부에 연 부조직 밀도의 방사선 비투과성이 관찰되었고 부분적으로 골 형성이 되었으나 전반적으로는 골재생이 관찰되지 않았다. BT군에서는 골이식재가 골변연부에 인접한 곳에서는 골재생 이 뚜렷하게 관찰되었지만, 변연부위에 인접하지 않은 곳에서 는 골재생이 미흡하였다. $\mathrm{PCB}$ 군에서는 전반적으로 균일하게 골재생이 관찰되었고 골변연부와 인접한 부위에서 BT군에 비 하여 골재생이 현저하게 관찰되었다(Fig. 2).

이미지 소프트웨어를 이용하여 흡광도를 측정·분석한 결과 골이식 후 4 주차에는 $\mathrm{CD}$ 군에 비해 $\mathrm{BT}$ 군과 $\mathrm{PCB}$ 군이 유의적으 로 높음을 확인할 수 있었다( $<<0.01, \mathrm{p}<0.01)$ (Table 1). 골이식 


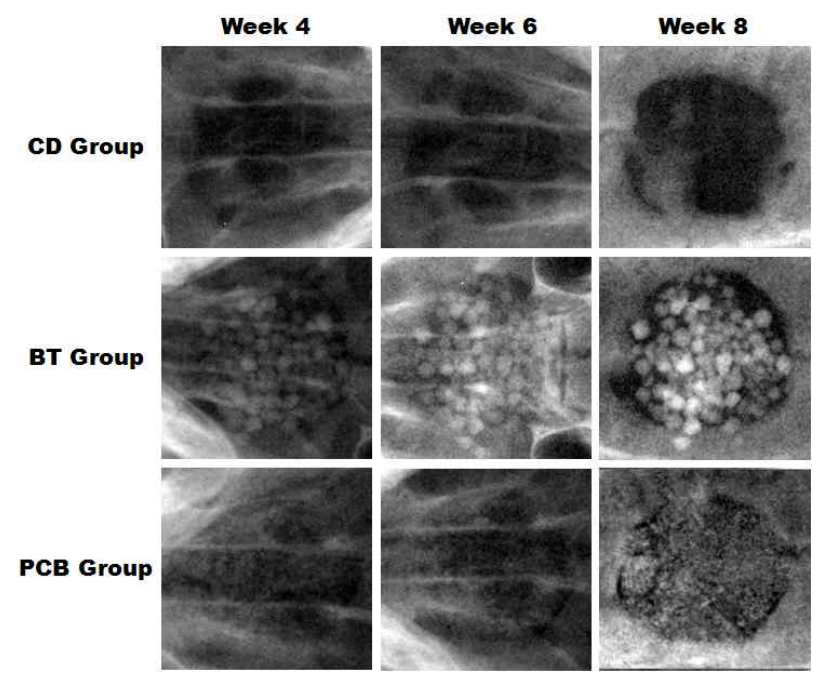

Fig. 2. Plain X-ray findings of the calvarial defects post bone grafting. At 4 weeks post grafting, no new bone is observed in defect in all groups. Six weeks post grafting, mild calcification is visible in defect in the BT group and $\mathrm{PCB}$, but not visible in the $\mathrm{CD}$ group. Eight weeks post grafting in the $\mathrm{CD}$ group, only small areas of calcification at periphery of defect is observed. In the BT group, more calcification but not fused with bone defect margins. In the PCB group more calcification and fused with bone defect margins than BT group. $C D=C r i t i c a l$ defect, $\mathrm{BT}=$ Beta-tricalcium phosphate, $\mathrm{PCB}=$ Porcine cancellous bone.
Table 1. Optical density of implantation site in rat calvarial bone 8 weeks after surgical procedure

\begin{tabular}{ccccc}
\hline Group & $\mathrm{n}$ & $4 \mathrm{wk}$ & $6 \mathrm{wk}$ & $8 \mathrm{wk}$ \\
\hline CD & 10 & $1.35 \pm 0.02$ & $1.16 \pm 0.02$ & $1.21 \pm 0.15$ \\
BT & 10 & $1.53 \pm 0.088^{* *}$ & $1.60 \pm 0.18^{* *}$ & $1.51 \pm 0.11^{*}$ \\
PCB & 10 & $1.5 \pm 0.04^{* *}$ & $1.57 \pm 0.14^{* *}$ & $1.67 \pm 0.09^{* *}$ \\
\hline
\end{tabular}

Values are expressed in mean \pm S.D. of 30 rats.

"Significantly different from CD group at $p<0.05$.

** Significantly different from CD group at $p<0.01$.

$\mathrm{CD}=$ Critical defect, $\mathrm{BT}=$ Beta-tricalcium phosphate, $\mathrm{PCB}=$ Porcine cancellous bone.

후 6주차에는 4 주차와 마찬가지로 $\mathrm{BT}$ 군과 $\mathrm{PCB}$ 군이 $\mathrm{CD}$ 군에 비해 유의적으로 높음을 확인할 수 있었다 $(\mathrm{p}<0.01, \mathrm{p}<0.01)$. 골이식 후 8 주차도 $\mathrm{CD}$ 군에 비해 $\mathrm{BT}$ 군과 $\mathrm{PCB}$ 군이 유의적으 로 높음을 확인할 수 있었다( $<<0.05, \mathrm{p}<0.01)$. 또한 $\mathrm{BT}$ 군과 $\mathrm{PCB}$ 군 사이의 유의적 차이는 존재하지 않았으나 $\mathrm{PCB}$ 에서의 흡광도가 가장 높았음을 확인할 수 있었다(Table 1). 또한 골 결손 변연부에서 $\mathrm{PCB}$ 군이 $\mathrm{BT}$ 군에 비해 두개결손부의 변연 에서 방사선 비투과성이 다른 군에 비해 증가됨을 육안으로 확인할 수 있었는데 이는 변연부에서 다른 군에 비해 골형성 관련 세포의 이주 및 혈관신생이 활발했음을 의미하는 것으로 생각된다.
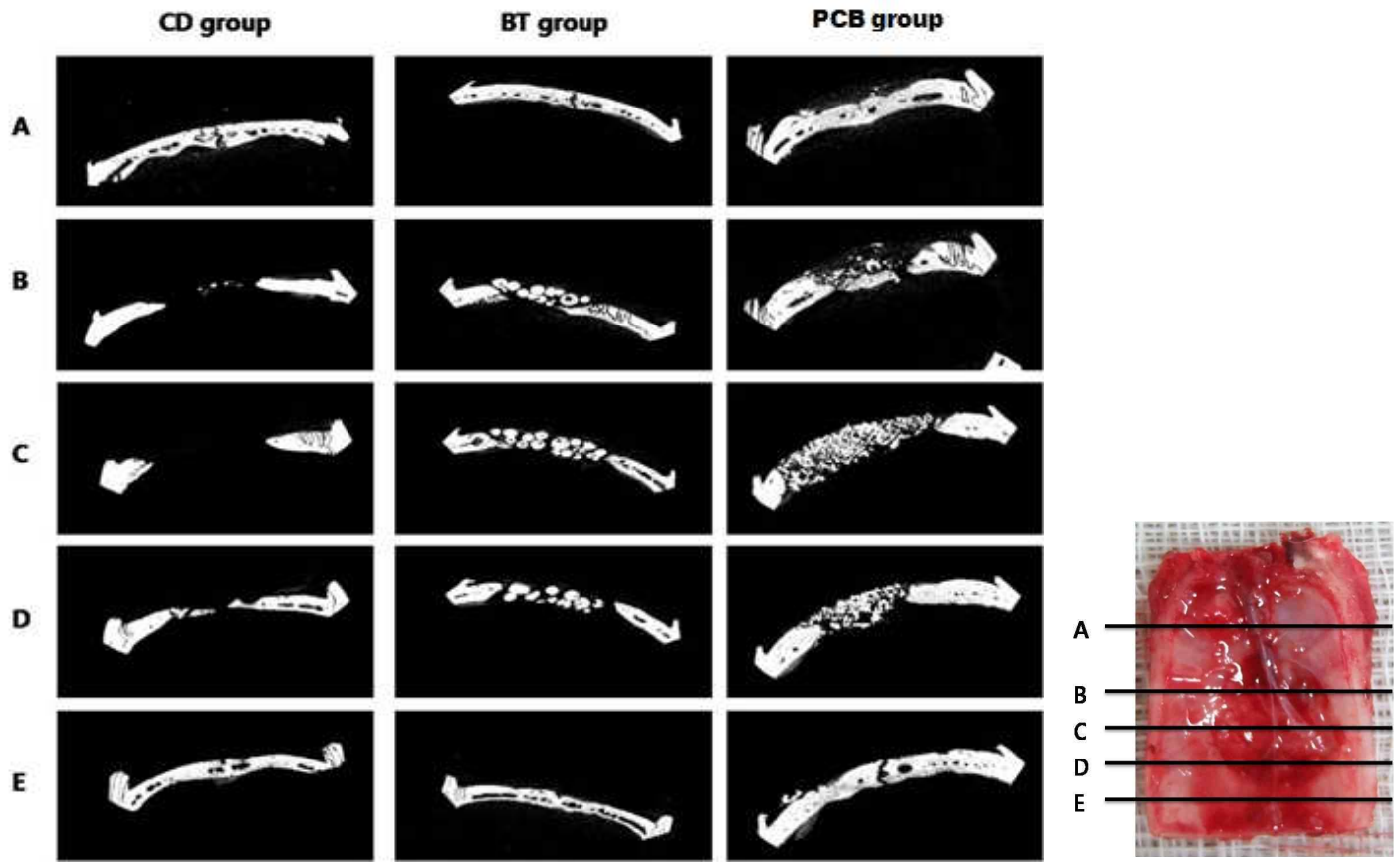

Fig. 3. Micro-computed tomograph images of bone regeneration at 8 weeks after bone graft surgery. Serial two-dimensional of micro-computed tomography of calvarial bone defect sites. CD group: there are very small size islands of new bone in center of the calvarial defect. BT group: calcification but not fused with bone defect margins. PCB group: more calcification than the $\mathrm{BT}$ group. $\mathrm{CD}=$ Critical defect, $\mathrm{BT}=$ Beta-tricalcium phosphate, $\mathrm{PCB}=$ Porcine cancellous bone. 


\section{Micro-CT 평가}

골이식 후 8 주차에 모든 실험군을 희생시킨 후 micro-CT를 이용하여 이식부를 중심으로 가로 $1.3 \mathrm{~cm}$, 세로 $1.6 \mathrm{~cm}$ 크기의 직사각형 모양으로 절단한 두개골을 촬영하였다. $\mathrm{CD}$ 군에서 는 결손부의 중앙부에 미약한 신생골의 생성을 볼 수 있었으 나 그 외의 부분에서는 골형성을 거의 찾아 볼 수 없었다(Fig. 3). BT군에서는 방사선 촬영소견과 마찬가지로 대부분의 이식 재가 구형의 모습을 그대로 간직하고 있었으며 결손부의 변연 부에는 신생골의 소견을 볼 수 없었다(Fig. 3). 현재 가장 많이 사용되는 수산화인회석은 반영구적인 이식재로 피질골 부위 에서는 부피비가 시간이 지남에 따라 점차적으로 감소하나 해면골 부위에서는 낮은 용해도로 인해 거의 부피 변화가 없 는 것으로 알려져 있다[13]. 이처럼 수산화인회석의 낮은 용해 도로 인해 오랜 기간 동안 안정적인 구조가 유지된다는 장점 이 있으나 자가골로 대체되는 비율이 현저히 떨어지는 단점을 가지게 되었다. 이러한 단점을 보완하기 위해 개발된 골이식
재가 바로 베타 삼인산칼슘으로 만든 다공성의 이식재이다. 베타 삼인산칼슘의 미세기공의 크기는 20-500 $\mu \mathrm{m}$ 이며, 자주 사용되는 크기는 50-125 $\mu \mathrm{m}$ 이다. 이러한 다공성의 베타 삼인 산칼슘은 미세기공으로 연결된 생체활성 재료로 수산화인회 석보다 높은 용해도를 보이며, 다른 인산칼슘(calcium phosphate) 세라믹재보다 빠른 흡수를 보이고, 골형성을 촉진하는 한편, 용출, 흡수의 과정을 거쳐 자가골로 치환될 수 있다고 보고되고 있다 5,20$]$. 본 연구에서 8 주 후 일반방사선과 micro-CT에서 이식된 삼인산칼슘 이식재는 부분적으로 흡수되 었지만, 전반적으로는 구형의 형태를 유지하고 있으면서 이식 재 내부에서 방사선비투과성이 증가하는 소견을 보였다. 이것 은 삼인산칼슘 이식재의 특성인 다공성으로 이식재 내부에서 흡수되면서 신생골이 형성되는 것을 의미하는 것으로 생각된다.

$\mathrm{PCB}$ 군에서는 이식재가 결손부 전반에 거쳐 골고루 분포되 어 있는 모습을 확인할 수 있었으며, 변연부에서도 BT군에 비 해 결손정도가 작아졌음을 확인할 수 있었고(Fig. 3), 이로 미
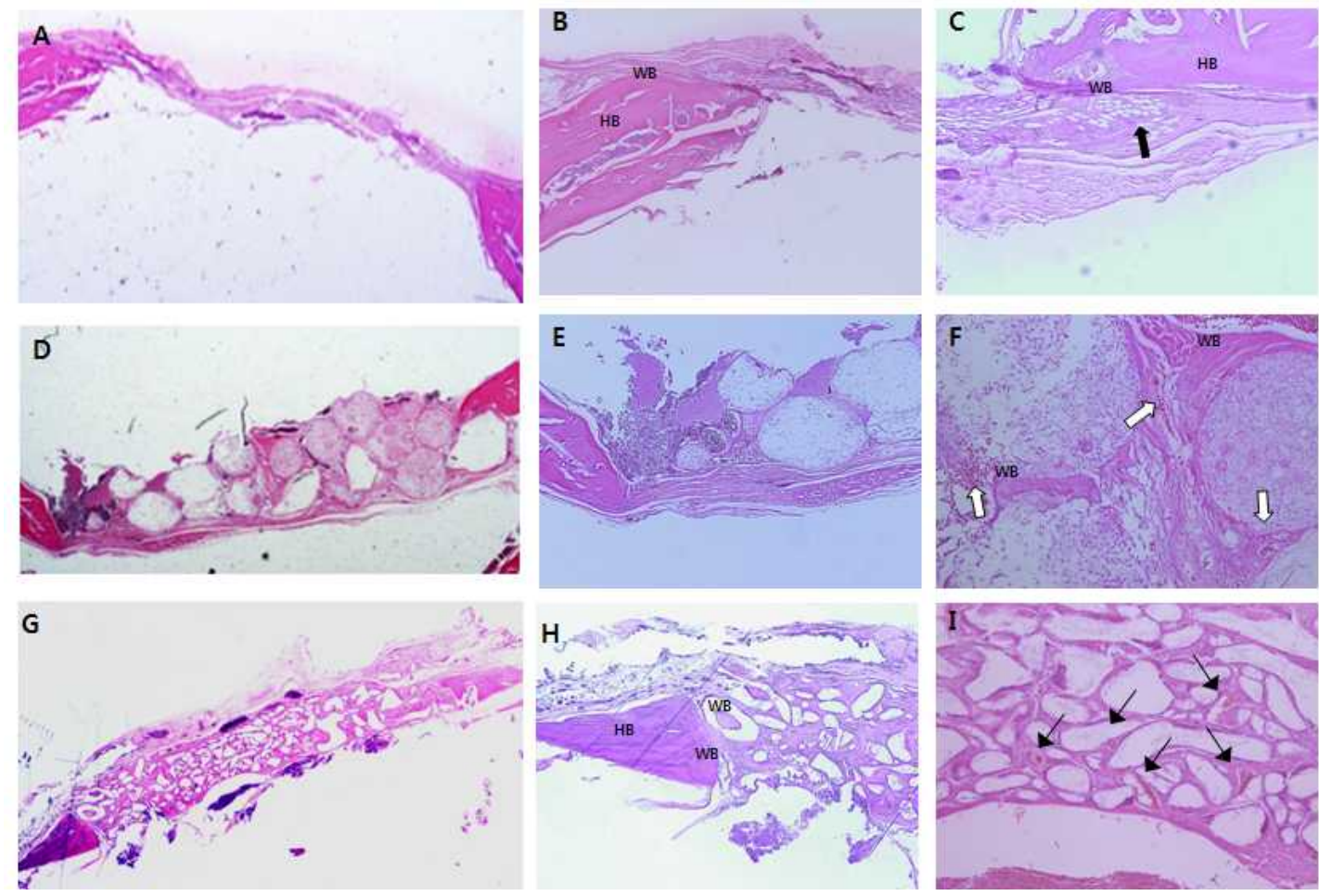

Fig. 4. The histological appearance of defect sites at 8 weeks post surgery in the calvarial defect groups. A (HE stain, $\times 10)$ and B (HE stain, $\times 40$ ): There are minimal quantity of new bone (woven bone) formation originating from the defect margins, C: Adipocytes can be observed from fibrous tissue (black arrow)(HE stain, $\times 100), \mathrm{D}(\mathrm{HE}$ stain, $\times 10)$ and $\mathrm{E}(\mathrm{HE}$ stain $\times 40$ ): Resorption/dissolution evident at $\beta$-TCP surfaces, F: New bone and angiogenesis (white arrows) apposition is frequently observed directly in between $\beta$-TCP particles in addition to cellular penetration of struts and phagocytic engulfing of $\beta$-TCP particles (HE stain $\times 100), G(H E$ stain, $\times 10)$ and H (HE stain, $\times 40)$ : There are quantity of new bone (woven bone) formation originating from the defect margins. Osteoids are formed between pores and into the pores of porcine cancellous bone, I: The surrounding new vessels can be observed within the pores of porcine cancellous bone (thin arrows) and cellular condensation on scaffold surfaces. It shows a mixture of new vessels, osteoid within the remodeled bone suggesting excellent osteoconduction (HE stain, $\times 100$ ). $\mathrm{WB}=$ woven bone, $\mathrm{HB}=$ host bone. 
루어볼 때 $\mathrm{PCB}$ 군에서의 골형성 정도가 가장 많았음을 관찰할 수 있었다. 또한 $\mathrm{PCB}$ 군에 사용된 돼지의 해면질골은 대퇴골이 나 경골을 추출하여 골에서 지방성 골수를 제거하고 고온 열 처리하여 단백질 또는 유기물질 등을 제거하여 면역반응을 최소화하였고, 합성에 의해 제조된 수산화인회석보다 생체적 합성이 뛰어나서 BT군보다 신생골 형성이 우수한 결과를 보 인 것으로 생각된다.

\section{조직병리학적 평가}

$\mathrm{CD}$ 군에서는 두개골결손부의 변연부에 층판뼈와 구분되는 소량의 무층빼(woven bone)가 관찰되었으나 그 정도는 매우 미약하였다. 결손부 전반적으로 골모세포, 염증세포 및 신생 혈관은 거의 관찰할 수 없었으며, 중심부에서는 신생골 형성 을 확인 관찰할 수 없었다. 변연부에서 집단으로 또는 개별적 으로 존재하는 성긴결합조직의 정상적인 구성요소인 지방세 포가 확인되었으며, 결손부 전반에 걸쳐 결합조직에서 많이 발견되는 길고 방추형의 섬유세포(fibrocyte)들이 많이 관찰되 었고, 결합조직이 두개결손부 전반에 채워져 있었다(Fig. $4 \mathrm{~A}$, $\mathrm{B}, \mathrm{C})$. 이러한 결과는 Schmitz 등의 연구[17]에서 말한 소견과 일치하였다.

BT군에서는 두개결손변연부에서 6마리 중 1마리에서 국소 적으로 중증도의 염증소견을 관찰할 수 있었고 이러한 염증이 수술 중 오염에 의한 것인지, 수술 후의 외부 요인에 의한 감염 인지는 확인할 수는 없으나, 모든 실험절차가 무균적으로 수 행되기 때문에 이식제에 대한 생체 거부반응에 의한 단순으로 생각된다. 골결손 부위의 변연부에서는 소량의 무층배가 형성 되었음을 확인할 수 있었으나 골의 성숙을 의미하는 층판뼈는 관찰할 수 없었다(Fig. $4 \mathrm{D}, \mathrm{E}, \mathrm{F})$. 골이식재 중 일부가 흡수되어 초기의 원형 모양을 유지하지 못하였고 골이식재 사이에 신생 골의 형성을 확인할 수 있었다. 또한 골이식재 내부에도 외부 에 비해 생성량은 적었지만 신생골이 형성되고 있음을 관찰할 수 있었다. 혈관의 신생은 골이식재 외부에서 주로 관찰되었 으며, 내부에서는 거의 확인할 수 없었다(Fig. $4 \mathrm{~F})$.

$\mathrm{PCB}$ 군에서는 두개결손부의 변연에서 무층뼈가 $\mathrm{CD}$ 군이나 BT군에 비해 많이 형성되어 있음을 확인할 수 있었다. 또한 이식재의 내부에서도 신생골의 형성을 확인할 수 있었다. 신 생골량도 다른 군에 비해 많은 양이 생성됨을 확인 할 수 있었 다. 특히 미세기공 외부는 골모세포로 이루어진 긴 선 (osteoblastic linings)들이 관찰 되었으며, 미세기공 사이에 혈 관 신생도 많이 관찰되었고 BT군에 비해 더 많은 이식재 내·외 부에 신생골 형성의 증거들을 확인할 수 있었다(Fig. $4 \mathrm{G}, \mathrm{H}$, I). BT군과 달리 염증세포의 침윤은 확인할 수 없었음으로 미 루어보아 골이식에 있어 베타 삼인산칼슘보다 돼지 해면질골 이 더 효과적인 결과를 보였음을 확인할 수 있었다. 이상의 결과들을 종합해보면 랫드의 두개골결손부 모델에서 돼지 해 면질골이 골재생 및 치유에 효과적임을 확인할 수 있었다. 그
러나 이종골이나 합성골과 같이 골형성능 및 골유도능 없이 골전도능만을 갖는 이식재의 이식 시 성공률을 높이기 위해 골형성을 가지는 세포 및 성장인자를 같이 이식하는 방법에 대한 연구가 필요하리라 생각된다.

\section{감사의 글}

이 논문은 2007년 정부(교육과학기술부)의 재원으로 한국 연구재단의 지원을 받아 수행된 연구임(KRF-2007-331E00269).

\section{References}

1. Aichelmann-reidy, M. E. and R. A. Yukna. 1998. Bone replacement grafts: the bone substitutes. Dent. Cin. North Am 42, 491-503.

2. Arrington, E. D., W. J. Smith, H. G. Chambers, A. L. Bucknel, and N. A. Davino. 1996. Complications of iliac crest bone harvesting. Clin. Orthop. 329, 300-309.

3. Betz, R. R. 2002. Limitation of autograft and allograft: New synthetic solutions. Orthopedics 25, 561-570.

4. Bhaskar, S. N., J. M. Brady, L. Getter, M. F. Grower, and T. Driskell. 1971. Biodegradable ceramic implants in bone electron and light microscopic analysis. Oral Surg. Oral Med Oral Pathol. 32, 336-346.

5. Bucholz, R. W., A. Carlton, and R. Holmes. 1987. Hydroxyapatite and tricalcium phosphate bone graft substitutes. Orthop. Clin. North Am 18, 323-334.

6. Costantino, P. D. and C. D. Friedman. 1994. Synthetic bone graft substitutes. Otolaryngol. Cin. North Am 27, 1037-1075.

7. Cypher, T. J. and J. P. Grossman. 1996. Biological principles of bone graft healing. J. Foot Anke Surg. 35, 413-417.

8. Eppley, B. L., W. S. Pietrzak, and M. W. Blanton. 2005. Allograft and alloplastic bone substitutes: a review of science and technology for the craniomaxillofacial surgeon. $J$. Craniofac. Surg. 16, 981-989.

9. Goulet, J. A., L. E. Senunas, G. L. DeSilva, and M. L. Greenfeild. 1997. Autogenous iliac crest bone graft: Complications and functional assessment. Clin. Orthop. Rel. Res. 339, 76-81.

10. Hollinger, J. O., J. Brekke, E. Gruskin, and D. Lee. 1996. Role of bone substitutes. Clin. Orthop. 324, 55-65.

11. Kim, S. H., J. W. Shin, S. A. Park, Y. K. Kim, M. S. Park, J. M. Mok, W. I. Yang, and J. W. Lee. 2004. Chemical, structural properties, and osteoconductive effectiveness of bone block derived from porcine cancellous bone. J. Biomed Mater. Res. B Appl. Biomater. 68, 69-74.

12. Kishimoto, M., S. I. Kanemaru, M. Yamashita, T. Nakamura, Y. Tamura, H. Tamaki, K. Omori, and J. Ito. 2006. Cranial bone regeneration using a composite scaffold of Beta-tricalcium phosphate, collagen, and autologous bone fragments. Laryngoscope 116, 212-216. 
13. Martin, R. B., M. W. Chapman, N. A. Sharkey, S. L. Zissimos, B. Bay, and E. C. Shors. 1993. Bone ingrowth and mechanical properties of coralline hydroxyapatite $1 \mathrm{yr}$ after implantation. Biomaterials 14, 341-348.

14. Millis, L. D. and A. S. Martinez. 2003. Textbook of Small Animal Surgery. pp. 1875-1891, 3rd eds., Saunders. Philadelphia.

15. Mundy, G. R. 1993. Vision for the future in osteoporosis research. Osteoporosis Int. 2, 29-34.

16. Prokic, B. 1990. Comparative clinical study of porous hydroxyapatite and decalcified freeze-dried bone in human periodontal defects. J. Periodontol. 61, 399-404.

17. Schmitz, J. P., Z. Schwartz, J. O. Hollinger, and B. D. Boyan. 1990. Characterization of rat calvarial nonunion defects.
Acta. Anat. 138, 185-192.

18. Sogal, A. and A. J. Tofe. 1999. Risk assessment of bovine spongiform encephalopathy transmission through bone graft material derived from bovine bone for dental applications. J. Periodontol. 70, 1053-1063.

19. Wagner, J. R. 1991. A $3 \frac{1}{2}$-year clinical evaluation of resorbable hydroxyapatite OsteoGen ${ }^{\circledR}$ (HA Resorb) used for sinus lift augmentations in conjunction with the insertion of endosseous implants. J. Oral Implantol. 17, 152-164.

20. Wiltfang, J., K. A. Schlegel, S. Schultze-Mosgau, E. Nkenke, R. Zimmermann, and P. Kessler. 2003. Sinus floor augmentation with beta-tricalciumphosphate (beta-TCP): Does platelet-rich plasma promote its osseous integration and degradation? Clin. Oral Implants. Res. 14, 213-218.

\section{초록 : 랫드의 두개골 결손부에서 돼지 해면질골이 골재생에 미치는 영향}

유경훈 · 김세은 · 심경미 $\left.\right|^{1} \cdot$ 박현정 $^{2}$ 최석화 ${ }^{3} \cdot$ 강성수* $^{*}$

(전남대학교 수의과대학, ${ }^{1}$ 남부대학교 방사선학과, ${ }^{2}$ 제주대학교 수의과대학, ${ }^{3}$ 충북대학교 수의과대학)

본 연구의 목적은 랫드의 두개결손부 모델에서 돼지 해면질골을 지지체로 사용했을 때의 효과를 평가해보고자 하였다. 임계결손부의 형성은 30마리의 수컷 Sprague-Dawley 랫드에서 실시하였으며 동물들은 임계결손군(CD group, $\mathrm{n}=10)$, 베타 삼인산칼슘군(BT group, $\mathrm{n}=10$ ) 및 돼지 해면질골군(PCB group, $\mathrm{n}=10)$ 으로 나누었다. 각각의 결손부위는 피브린 글루와 혼합시킨 베타 삼인산칼슘 또는 돼지 해면질골로 채워졌으며 $\mathrm{CD}$ 군은 결손부위에 이 식재를 이식하지 않았다. 모든 랫드들은 골이식 수술 8 주 후에 희생되었으며 희생 후 육안검사, 단순 방사선촬영, micro-CT 촬영 및 조직검사를 통해 골형성 정도를 평가하였다. 결과에서 골결손부의 치유는 $\mathrm{CD}$ 군에서 가장 낮 았으며 PCB군에서는 유의성 있는 새로운 골형성을 확인할 수 있었다. 또한 방사선촬영 결과, 조직학적 평가 및 micro CT 촬영 결과에서 골이식 시 돼지 해면질골이 베타 삼인산칼슘보다 새로운 골형성에 있어 더욱 효과적임 을 관찰할 수 있었다. 